\title{
Genetic control of chemical induction of conjugation in Paramecium bursaria
}

\author{
Hiroshi Endoh*
}

\author{
Biological Institute, Tohoku University, Sendai 980, \\ Japan.
}

\begin{abstract}
In six out of 36 natural stocks of Paramecium bursaria examined, chemical induction of conjugation was successful when cells were cultured in Ca-poor medium and then treated with acriflavine and $\mathrm{KCl}$. Conjugation by the normal process following mixing of cells of opposite mating type occurred normally in these six stocks. Genetic analysis of chemical induction of conjugation was performed with three out of the six stocks. Chemical induction of conjugation was found to be controlled by recessive genes at two different loci, designated cic-1, cic-2. These genes are not linked to mating type loci. These inducible stocks showed additional features different from those of uninducible ones. When uninducible stocks were stimulated both by mating reaction and conjugation-inducing chemicals simultaneously, conjugation was drastically inhibited. Inducible stocks, by contrast, were free from such inhibition. The results suggest that there is a step blocked by the conjugation-inducing chemicals in the normal process of conjugation. This step is probably controlled by the cic loci.
\end{abstract}

\section{INTRODUCTION}

Conjugation in Paramecium can be induced in two different ways. One is normal conjugation induced by mixing complementary mating types. In normal conjugation, interaction of cells of complementary mating types activates the cells for pair formation. The other means of inducing conjugation is called the chemical induction of conjugation and was developed by Miyake $(1958,1968)$. In this type of conjugation, cells are activated for pair formation without the interaction of cells of complementary mating types.

Chemical induction of conjugation has made Paramecium a good model system for the study of activation in fertilisation. Another model system is that of artificial parthenogenesis in metazoan eggs (Metz, 1954; Hiwatashi, 1981, 1985). In particular, the discovery of mutants affecting chemical induction of conjugation has deepened the study of activation-initiating mechanisms (Cronkite, 1974, 1975). Furthermore, chemical induction of conjugation is useful for producing completely homozygous strains in species of Paramecium lacking natural autogamy. When conjugation is

* Present address: Institute of Biological Sciences, University of Tsukuba, Ibaraki 305, Japan. induced chemically, aberrant cell unions often occur (Miyake, 1958). In these cell unions, exchange of gamete nuclei is blocked because of the failure of face-to-face adhesion of paroral regions and fusion of identical haploid nuclei occurs, leading to the production of completely homozygous progeny, like those found after autogamy (Miyake, 1968). Though many species of Paramecium have been shown to undergo chemically induced conjugation, this has not previously been reported for Paramecium bursaria. As will be shown in this paper, most natural stocks of this species cannot be induced to conjugate by chemical treatment. However, in this paper, I now report some stocks of Paramecium bursaria in which conjugation is chemically inducible. A genetic analysis of these stocks is also described.

\section{MATERIALS AND METHODS}

\section{Stocks and culture methods}

The stocks and strains used in this study belong to Paramecium bursaria, syngen 1. Stocks Nn7, T151, Mts5, d-492 and FF12 can be induced to conjugate by chemical treatment. Mts4 and T81C2 are uninducible stocks. Nn7, T151, Mts5 and Mts4 
are natural stocks and all others are strains derived from crosses or artificially induced cytogamy (Endoh, unpublished). T81C2 is a complete homozygote derived from the natural stock T81. This homozygous strain was obtained by artificial induction of cytogamy by a method similar to that of Orias et al. (1979) in Tetrahymena.

Culture medium used for the cultures was sterilised fresh lettuce juice inoculated with Klebsiella pneumoniae 1-2 days before use (Hiwatashi, 1968). Ca-poor lettuce juice medium in which the juice was diluted with $2 \mathrm{mM}$ sodium phosphate buffer ( $p \mathrm{H} \mathrm{6.4)} \mathrm{instead} \mathrm{of} \mathrm{Dryl's} \mathrm{solution} \mathrm{was} \mathrm{used}$ for culturing cells for chemical induction of conjugation. All cultures were kept at $25^{\circ} \mathrm{C}$ under the $16: 8$ (hour) light-dark cycle. All experiments were carried out at midday when mating reactivity was the strongest in the circadian cycle (Cohen, 1964).

\section{Chemical induction of conjugation}

Chemical induction of conjugation was carried out according to the methods of Miyake (1958, 1968). Mating reactive cells cultured in $\mathrm{Ca}$-poor medium were washed twice and suspended in physiological balanced solution (PBS) containing $1.5 \mathrm{mM} \mathrm{NaCl}$, $0.05 \mathrm{mM} \mathrm{KCl}, 0.1 \mathrm{mM} \mathrm{MgCl}$ and $0.01 \mathrm{mM} \mathrm{CaCl}_{2}$ in $2 \mathrm{mM}$ phosphate buffer ( $p \mathrm{H} \mathrm{6.4)}$. The cell suspension was mixed in a test tube with an equal volume of the conjugation-inducing medium (4$8 \mathrm{mM} \mathrm{KCl}, \quad 20-80 \mu \mathrm{g} / \mathrm{ml}$ acriflavine, $100 \mathrm{mM}$ acetamide in PBS). When successful, conjugation was induced in 2 hours in this medium (Endoh, 1987).

\section{Crossing technique and identification of the phenotypes}

When cells of complementary mating types are mixed, initial cell agglutination (mating reaction) occurs between complementary cells. In order to confirm conjugating pairs to be true cross pairs, cells were marked by the presence or absence of symbiotic algae in every cross breeding analysis, although selfing conjugation does not occur in $P$. bursaria under normal conjugation (Larison and Siegel, 1961; Endoh et al., 1987). Six to ten hours after initiation of the mating reaction, conjugating pairs were isolated into depression slides containing Dryl's solution and kept in this solution. Three days later, fresh culture medium was added to each depression and cells were cultured in this medium for 3-4 days. After growth to $20-40$ cells, a single cell from each depression was isolated (sub-caryonidal isolation) and cultured for another 3-4 more days. Then almost all cells in each depression were transferred into a test tube. Established clones were tested for their mating reactivity. MR (macronuclear regeneration) clones which show high mating reactivity were discarded. True exconjugant clones would be in the period of immaturity and nonreactive. When clones became mature after successive transfers of culture, their capability to undergo chemical induction of conjugation was examined. Uninducible clones were cultured again and about 15 fissions (three tube transfers) after the first test, the test for chemical induction was repeated. In this way, the inducibility of each stock was tested at least three times.

\section{RESULTS}

\section{Chemical induction of conjugation in natural stocks}

Thirty-six natural stocks of $P$. bursaria, syngen 1 , mainly collected in Japan, were examined for chemical induction of conjugation. Typical conjugants induced chemically are shown in fig. 1. As seen in table 1 , six stocks among 36 examined were found to be chemically inducible. These six induc-

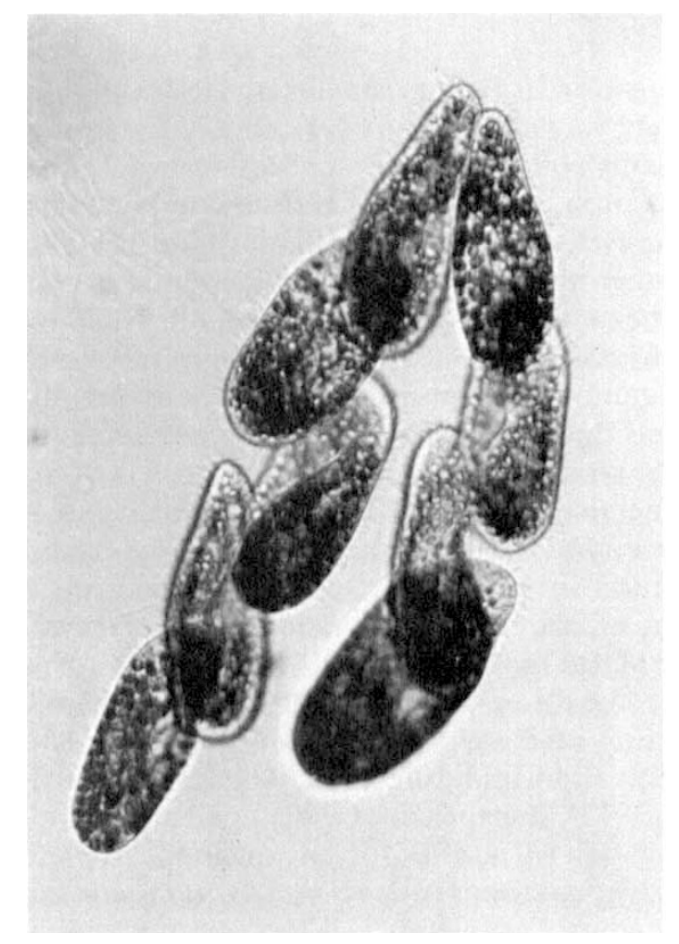

Figure 1 A typical conjugating union induced chemically. Stock: T151 (IV). 
Table $1 P$. bursaria stocks tested for their capability of chemical induction of conjugation

\begin{tabular}{|c|c|c|c|}
\hline Stock & $\begin{array}{l}\text { Mating } \\
\text { type }\end{array}$ & $\begin{array}{l}\text { Geographic } \\
\text { origin }\end{array}$ & $\begin{array}{l}\text { Chemical induction } \\
\text { of conjugation }\end{array}$ \\
\hline Ih 1 & I & Iwate & - \\
\hline $\mathrm{Yt} 2$ & III & Yamagata & - \\
\hline $\mathrm{Yt3}$ & III & & - \\
\hline Yt4 & IV & & - \\
\hline M3 & III & Miyagi & - \\
\hline M4 & II & & - \\
\hline M5 & II & & - \\
\hline Tk1 & I & Tochigi & - \\
\hline $\mathrm{T} 151$ & IV & Ibaraki & $\mathrm{H}$ \\
\hline T157 & II & & - \\
\hline T171 & III & & $\mathrm{H}$ \\
\hline T172 & II & & - \\
\hline T316 & IV & & - \\
\hline T81 & III & & - \\
\hline $\mathrm{T} 81 \mathrm{C} 2$ & III & & - \\
\hline $\mathrm{Cw}$ & III & & - \\
\hline $\mathrm{Bg}$ & I & & - \\
\hline Nn1 & II & Niigata & $\mathrm{L}$ \\
\hline $\mathrm{Nn} 4$ & III & & - \\
\hline $\mathrm{Nn} 5$ & IV & & - \\
\hline Nn6 & II & & - \\
\hline $\mathrm{Nn} 7$ & IV & & $\mathrm{H}$ \\
\hline $\mathrm{Nn} 8$ & IV & & $\mathrm{H}$ \\
\hline So5 & III & Nagano & - \\
\hline Sol1 & I & & - \\
\hline So 13 & II & & - \\
\hline So 15 & IV & & - \\
\hline Mts1 & IV & & - \\
\hline Mts3 & III & & - \\
\hline Mts4 & I & & - \\
\hline Mts5 & II & & $\mathrm{L}$ \\
\hline Ok1 & I & Aichi & - \\
\hline $\mathrm{Ok} 2$ & III & & - \\
\hline Ok3 & II & & - \\
\hline $\mathrm{Cs} 2$ & II & Shanghai, China & - \\
\hline
\end{tabular}

${ }^{a} \mathrm{H}$ : Highly inducible; L: Barely inducible; -: Uninducible; See text in detail

ible stocks were collected from three different places and were divided into two groups by the extent of conjugation induced. One group consisting of $\mathrm{Nn} 7, \mathrm{~T} 151, \mathrm{Nn} 8$ and T171 showed a high frequency of conjugation, usually more than 50 per cent. The second group consisting of $\mathrm{Nn} 1$ and Mts5 showed low frequency of conjugation, never above 10 per cent. These data show that in natural populations of $P$. bursaria, chemically uninducible stocks are common and widely distributed, while the inducible ones are relatively uncommon. This is just the opposite situation to P. octaurelia where the uninducible trait was mutant (Cronkite, 1974, 1975).
Genic control of the chemical induction of conjugation

Breeding analyses were carried out with the three stocks Nn7, T151 and Mts5. Nn1, Nn8 and T171 have not been genetically analysed because of their poor survival after conjugation. Table 2(a) shows the results of crossing together inducible and uninducible stocks, and the mating types of the progeny obtained. Mating types are determined by specific combination of pairs of alleles at two independently assorting loci. Mating type $I$ is brought about by dominant alleles at loci $A$ and $B$; type III is determined by the double recessive genotype 
$(a a b b)$; type II $(a a B B$ or $a a B b)$ and IV $(A A b b$ or $A a b b)$ are determined by recessive alleles at one or the other of the two loci in combination with at least one dominant gene at other locus (Siegel and Larison, 1960, Siegel, 1963). When the original stocks $\mathrm{Nn} 7$ and T151 were used, high lethality was observed in $F_{2}$ and the segregation of mating type markers was much distorted. For this reason, the $\mathrm{F}_{2}$ segregants, d-Nn7 and d-T151 which showed good fertility, used for the cross breeding analyses. When the chemical inducible strain d-Nn7 derived from $\mathrm{Nn} 7$ was crossed to the chemically uninducible $\mathrm{T} 81 \mathrm{C} 2$, all $\mathrm{F}_{1}$ clones showed the chemically uninducible phenotype. When $F_{2}$ progeny were obtained by a sibling cross of $F_{1}$, uninducible and inducible clones segregated in a ratio not significantly different from $3: 1$. In order to classify the phenotypes, I repeated the test three to five times. The results suggest that the chemically inducible phenotype of stock $\mathrm{Nn} 7$ is controlled by a single recessive gene.

The same kind of genetic analysis was performed with another chemically inducible strain, dT151 derived from T151. As seen in table 2(b), the results were almost the same as those of $\mathrm{d}-\mathrm{Nn} 7$ and again the segregation ratio of the trait in $F_{1}$ and $F_{2}$ was consistent with a one gene hypothesis.

Chemical induction of conjugation in stock Mts5 was a little different from that of the former two stocks (d-Nn7 and d-T151). The chemically induced conjugation was classified as "low" in Mts5, as shown in table 1 . In this case, mating types are determined by only $B$ locus because mating type II and III is recessive homozygous at $A$ locus. When Mts5 was crossed to the uninducible stock, T81C2, the phenotypes of the progeny could not be allocated to two categories of inducible and uninducible (table $2(\mathrm{c})$ ). About 10 per cent of $F_{1}$ $(4 / 37)$ were inducible but the conjugation frequency induced was very low. When two $F_{1}$ clones with low inducibility were selected and sibcrossed to produce an $F_{2}$, the segregation ratio of chemically uninducible to inducible trait was not significantly different from the expected ratio of $3: 1$ although segregation of mating types was not normal. Biased segregation ratio of mating types may be due to the close linkage between mating type gene and lethal gene. If I assume that dominance of uninducible character over inducible one is not complete and some heterozygotes show low inducibility, $F_{1}$ and $F_{2}$ segregations conform to simple Menderian inheritance. To verify this hypothesis, $F_{1}$ clone with low inducibility was backcrossed to the original stocks Mts5 with low inducibility. As expected, uninducible plus barely inducible progeny to highly inducible progeny segregated $3: 1$. Segregation of mating type markers was also as expected. These results show that Mts 5 is heterozygous for the gene controlling the chemical induction of conjugation, and that

Table 2 Breeding analyses of the trait for chemical induction of conjugation

\begin{tabular}{|c|c|c|c|c|c|c|c|c|c|c|c|c|}
\hline & \multirow[b]{2}{*}{ Cross } & \multirow{2}{*}{$\begin{array}{l}\text { (Mating type } \\
\text { :genotype) }\end{array}$} & \multicolumn{3}{|c|}{$\begin{array}{l}\text { Chemical induction } \\
\text { of conjugation }\end{array}$} & \multirow{2}{*}{\multicolumn{2}{|c|}{$\begin{array}{l}\text { Deviation } \\
\text { from } 1: 3\end{array}$}} & \multicolumn{4}{|c|}{ Mating type } & \multirow{2}{*}{$\begin{array}{l}\text { Deviation } \\
\text { from } 1: 1: 1: 1\end{array}$} \\
\hline & & & \multicolumn{3}{|c|}{ Inducible: Uninducible } & & & \multicolumn{4}{|c|}{ : II : III : IV } & \\
\hline (a) & $\begin{array}{l}\mathrm{d}-\mathrm{Nn} 7^{\mathrm{a}} \\
\times\end{array}$ & $(\mathrm{I}: A a B b) \mathrm{F}_{1}$ & 0 & 45 & & - & & 13 & 10 & 12 & 10 & $0.8<P$ \\
\hline \multirow{5}{*}{ (b) } & $\mathrm{T} 81 \mathrm{C} 2$ & $(\mathrm{III}: a a b b) \mathrm{F}_{2}$ & 19 & 63 & & $0.7<P$ & & 18 & 23 & 20 & 21 & $0.8<P$ \\
\hline & $\begin{array}{l}\mathrm{d}-\mathrm{T} 151^{\mathrm{b}} \\
\times\end{array}$ & $(\mathrm{I}: A a B b) \mathrm{F}_{1}$ & 0 & 39 & & - & & 10 & 9 & 11 & 9 & $0.95<P$ \\
\hline & $\mathrm{T} 81 \mathrm{C} 2$ & $(\mathrm{III}: a a b b) \mathrm{F}_{2}$ & 24 & 66 & & $0.7<P$ & & 20 & 22 & 22 & 26 & $0.8<P$ \\
\hline & \multirow[b]{2}{*}{ Cross } & \multirow[b]{2}{*}{$\begin{array}{l}\text { (Mating type } \\
\text { :genotype) }\end{array}$} & \multicolumn{4}{|c|}{$\begin{array}{l}\text { Chemical induction } \\
\text { of conjugation }\end{array}$} & \multirow{2}{*}{\multicolumn{3}{|c|}{$\begin{array}{l}\text { Deviation } \\
\text { from } 1: 3\end{array}$}} & \multicolumn{2}{|c|}{ Mating type } & \multirow[b]{2}{*}{$\begin{array}{l}\text { Deviation } \\
\text { from } 1: 1\end{array}$} \\
\hline & & & $\begin{array}{l}\text { Highly } \\
\text { inducible }\end{array}$ & \multicolumn{3}{|c|}{$\begin{array}{l}\text { Barely } \\
\text { : inducible: Uninducible }\end{array}$} & & & & II & : III & \\
\hline \multirow[t]{4}{*}{ (c) } & $\begin{array}{l}\mathrm{Mts}^{\mathrm{c}} \\
\times\end{array}$ & $(\mathrm{II}: a a B b) \mathrm{F}_{1}$ & 0 & 4 & 33 & & - & & & 17 & 20 & $0.6<P$ \\
\hline & $\mathrm{T} 81 \mathrm{C} 2$ & $(\mathrm{III}: a a b b) \mathrm{F}_{2}$ & 7 & 4 & 25 & & $0.4<P$ & & & 26 & 10 & $P<0.001$ \\
\hline & $\begin{array}{l}\mathrm{F}_{1}^{\mathrm{d}} \\
\times\end{array}$ & $(111: a a b b) \mathrm{BC}$ & 11 & 1 & 26 & & $0.4<P$ & & & 21 & 17 & $0.4<P$ \\
\hline & Mts5 & $(\mathrm{II}: a a B b)$ & & & & & & & & & & \\
\hline
\end{tabular}

\footnotetext{
${ }^{\mathrm{a}} \mathrm{F}_{2}$ segregant from the cross $\mathrm{Nn} 7 \times \mathrm{Mts} 4 .{ }^{\mathrm{b}} \mathrm{F}_{2}$ segregant from the cross $\mathrm{T} 151 \times \mathrm{Mts} 4 .{ }^{\mathrm{c}}$ A natural stock (See table 1). ${ }^{\mathrm{d}}$ A segregant with barely inducible trait. ${ }^{\mathrm{e}}$ Assuming highly inducible clones are homozygous recessive.
} 
Table 3 Complementation analyses among three conjugation inducible stocks

\begin{tabular}{|c|c|c|c|c|c|}
\hline \multirow{2}{*}{$\begin{array}{l}\text { Cross } \\
\text { (Mating type: genotype) }\end{array}$} & \multirow{2}{*}{$\begin{array}{c}\begin{array}{c}\text { Chemical induction } \\
\text { of conjugation }\end{array} \\
\text { Inducible: uninducible }\end{array}$} & \multicolumn{3}{|c|}{ Mating type } & \multirow{2}{*}{$\begin{array}{l}\text { Deviation } \\
\text { from } 1: 1: 1: 1 \\
\text { or } 3: 1: 1: 3\end{array}$} \\
\hline & & I & II & III :IV & \\
\hline $\begin{array}{l}\mathrm{FF} 12^{\mathrm{a}} \times \mathrm{Nn} 7 \\
(\mathrm{II}: a a B b)(\mathrm{IV}: A a b b)\end{array}$ & 53 & 15 & 12 & $13 \quad 13$ & $0.9<P$ \\
\hline $\begin{array}{ll}\mathrm{FF} 12^{\mathrm{a}} \times \mathrm{T} 151 \\
(\mathrm{II}: a a B b) & (\mathrm{IV}: A a b b)\end{array}$ & $41^{b}$ & 9 & 12 & $8 \quad 12$ & $0.7<P$ \\
\hline $\begin{array}{ll}\text { Nn7 } \times & \text { d }-492^{c} \\
(I V: A a b b) & (\mathrm{I}: A a B b)\end{array}$ & 94 & 35 & 12 & $10 \quad 37$ & $0.9<P$ \\
\hline
\end{tabular}

${ }^{a}$ FF12 is an $F_{2}$ segregant with highly inducible trait derived from the cross Mts5 $\times$ T81C2 (See table 2(c)).

${ }^{\mathrm{b}}$ Segregants with barely inducible trait were counted as uninducible. ${ }^{\mathrm{c}} \mathrm{d}-492$ is an $\mathrm{F}_{2}$ segregant derived from the cross d-T151 $\times$ Mts4 (See table 2(b)).

the dominancy of uninducible character is not complete.

\section{Complementation analyses}

In order to determine the number of loci controlling the chemical induction of conjugation, complementation analyses were performed (table 3 ). In the complementation experiments, four different strains with high inducibility were used. $\mathrm{Nn} 7$ and T151 are natural stocks and homozygous for a gene controlling chemical induction of conjugation (table 2(a) and 2(b)). FF12 is a highly inducible segregant from the backcross in table 2(c). d-492 is a highly inducible $F_{2}$ segregant derived from T151 $\times$ Mts 4 . When FF12 was crossed to $\mathrm{Nn} 7$, all progeny were chemically inducible. This shows that inducibility of FF12 and $\mathrm{Nn} 7$ is controlled by the same locus. On the contrary, the remaining two crosses $(\mathrm{Nn} 7 \times \mathrm{d}-492, \mathrm{FF} 12 \times \mathrm{T} 151)$ produced uninducible progeny. These results suggest that the chemically inducible phenotype of T151 and d-492 (derived from T151) is controlled by a locus different from the one controlling FF12 and $\mathrm{Nn} 7$. Both genes were not linked to the mating type loci. The locus controlling Mts 5 and $\mathrm{Nn} 7$ is designated as cic-1, and that controlling T151 as cic-2, indicating the first letters of the three words, chemical induction of conjugation.

\section{Simultaneous stimulation}

When cells were stimulated simultaneously by mating reaction and by conjugation-inducing chemicals, the induction of conjugation in uninducible stocks was very different from that in the inducible ones. When conjugation between uninducible stocks was induced by mating types in PBS, the conjugation ratio reached 50-85 per cent.
However, when conjugation between uninducible stocks was induced by mating types in conjugationinducing chemicals, conjugation ratio decreased drastically (table 4). On the contrary, when conju-

Table 4 Inhibition of conjugation by simultaneous stimulation with mating reaction and conjugation-inducing chemicals

\begin{tabular}{|c|c|c|}
\hline \multirow[b]{2}{*}{ Cross } & \multicolumn{2}{|c|}{$\%$ conjugation } \\
\hline & $\mathrm{PBS}^{\mathrm{a}}$ & $\mathrm{CIC}^{\mathrm{b}}$ \\
\hline \multicolumn{3}{|l|}{ "Uninducible" } \\
\hline Sol $5 \times$ Mts 4 & $63 \cdot 6$ & $5 \cdot 7$ \\
\hline $\mathrm{T} 316 \times \mathrm{Yt} 5$ & $64 \cdot 6$ & $11 \cdot 5$ \\
\hline Ok1 $1 \times$ Mtsl & $85 \cdot 2$ & $35 \cdot 5$ \\
\hline $\mathrm{Ok} 1 \times \mathrm{T} 316$ & $50 \cdot 4$ & $1 \cdot 8$ \\
\hline Mts $1 \times M t s 3$ & $59 \cdot 6$ & $1 \cdot 0$ \\
\hline \multicolumn{3}{|l|}{ "Inducible" } \\
\hline $\mathrm{Nn} 7(c i c-1 / c i c-1) \times \mathrm{FF} 12(c i c-1 / c i c-1)$ & $83 \cdot 4$ & $88 \cdot 9$ \\
\hline $\operatorname{T} 151(c i c-2 / c i c-2) \times 87-8^{c}(c i c-2 / c i c-2)$ & $63 \cdot 7$ & $75 \cdot 2$ \\
\hline $\mathrm{FF} 12(c i c-1 / c i c-1) \times \mathrm{T} 151(c i c-2 / c i c-2)$ & $74 \cdot 3$ & $77 \cdot 8$ \\
\hline
\end{tabular}

${ }^{a}$ PBS: Physiological balanced solution. ${ }^{b} \mathrm{CIC}$ : Conjugationinducing chemicals. ${ }^{\mathrm{c}}$ An $\mathrm{F}_{2}$ segregant from the cross $\mathrm{T} 151 \times$ Mts4.

gation between the chemically inducible stocks was induced by mating reaction and conjugationinducing chemicals, the ratio did not decrease but even increased slightly. In both cases, the initial mating reaction was not inhibited. In the uninducible stocks, the mating reaction in the conjugationinducing chemicals continued at least 2 hours and thereafter most of the cell agglutinates were gradually broken up into single cells without releasing conjugating pairs. Such inhibition of the induction of conjugation never occurred when cells were homozygous for either of the cic genes. These results suggest that in the mating-type induced conjugation process, there is a step which is blocked by the conjugation-inducing chemicals. 


\section{DISCUSSION}

Chemical induction of conjugation has previously not been successfully achieved in members of the "bursaria" group of Paramecium species, except for one selfing strain in P. trichium (Miyake, 1968). In the work reported here, 36 stocks were examined (table 1) for chemical inducibility of conjugation and it was found that only six of them could be induced to conjugate. Strains of $P$. bursaria capable of responding to chemical induction of conjugation appear to be distributed in widely scattered locations.

By genetic analysis, two loci controlling the susceptibility to chemical induction of conjugation were discovered. The susceptible stocks are recessive homozygotes of either of the two loci, cic-1 and cic-2. When mating types of uninducible cells are mixed in the conjugation-inducing chemicals, strong mating reaction lasts for more than 2 hours but only very few pairs are induced. This inhibition of conjugation in mating type mixtures in the conjugation-inducing medium was not observed with the cic inducible stocks (table 4). Probably, the conjugation-inducing chemicals are acting on some steps of transition from mating reaction to pair formation and thus inhibiting the formation of pairs. In the cic mutants, this step which is susceptible to the conjugation-inducing chemicals is defective so that induction of pairs cannot be inhibited.

In P. octaurelia, Cronkite (1974) reported kau mutants which can be induced to conjugate by mating types but not by chemicals. There are two differences between the kau mutants in $P$. octaurelia and the cic inducible stocks in $P$. bursaria. Recessive mutations change cells from susceptible to non-susceptible to conjugationinducing chemicals in the former species but from non-susceptible to susceptible in the latter. The other difference is the result of simultaneous stimulation by mating reaction and conjugationinducing chemicals. The simultaneous stimulation inhibits conjugating pair formation both in inducible wild type and the uninducible mutants in $P$. octaurelia but only in uninducible stocks, not in the inducible ones in P. bursaria.

Kitamura $(1982,1984)$ reported that mating reactive cells of Paramecium tend to attach on hydrophobic surfaces such as the polystyrene surface and suggested that some kind of hydrophobic interactions on ciliary membranes is involved in the early step of the induction of conjugation. He hypothesised the possibility that the site for the hydrophobic interactions may be the receptor site for chemical induction of conjugation. An interesting observation of Kitamura (1985) in relation to this study is that hydrophobicity of mating reactive ciliary surfaces of $P$. bursaria (uninducible stocks) appears very low comparing with that of other species of Paramecium. This fact may be in some way related to the low susceptibility of uninducible stocks of $P$. bursaria to conjugation-inducing chemicals. This possible relationship can be tested by comparing the hydrophobicity of mating reactive ciliary surfaces between uninducible stocks and the cic inducible stocks.

In $P$. caudatum and $P$. octaurelia, when chemical induction of conjugation was successful, cells settle to the bottom of containers and start to whirl a few minutes after cells are transferred into conjugation-inducing chemicals (Miyake, 1958; Cronkite, 1979; Kitamura and Hiwatashi, 1984). This inactivation of cell movement in conjugationinducing chemicals never occurs when cells were in non-mating reactive stages or mutants unable to respond to the chemicals and thus gives us a clear prediction of successful induction of conjugation in those two species of Paramecium. Unexpectedly in $P$. bursaria, however, the situation was just the opposite. Cell movement of the cic inducible stocks was not inactivated in conjugationinducing chemicals even though they were induced to conjugate chemically. On the contrary, chemically uninducible cells showed inactivation of cell movement in the chemicals (Endoh, unpublished). At present, I can find no good reason to explain these apparent contradictory phenomena.

Acknowledgement I thank Professor K. Hiwatashi, Tohoku University, for helpful comments and critical readings of the manuscript.

\section{REFERENCES}

COHEN, L. W. 1964. Diurnal intracellular differentiation in Paramecium bursaria. Exp. Cell Res., 36, 398-406.

CRONKITE, D. L. 1974. Genetics of chemical induction of conjugation in Paramecium aurelia. Genetics, 76, 703-714.

CRONKITE, D. L. 1975. A supressor gene involved in chemical induction of conjugation in Paramecium aurelia. Genetics, $80,13-21$.

CRONKITE, D. L. 1979. The genetics of swimming and mating behavior in Paramecium. In Levandows, M. and Hunter, S. H. (eds) Biochemistry and Physiology of Protozoa, 2nd ed., Vol. 3, Academic Press, New York, pp. 221-273.

ENDOH, H. 1987. Interspecific conjugation between distantly related species of Paramecium. Jpn. J. Genet., 62, 21-25.

ENDOH, H., WATANABE, T. AND HiWATASHi, K. 1987. Artificial induction of selfing conjugation in Paramecium bursaria. J. Exp. Zool., 241, 333-338.

HIWATASHI, K. 1968. Determination and inheritance of mating type in Paramecium caudatum. Genetics, 58, 373-386. 
HIWATASHI, K. 1981. Sexual interactions of the cell surface in Paramecium. In O'Day, D. H. and Horgen, P. A. (eds) Sexual Interactions in Eukaryotic Microbes, Academic Press, New York, pp. 351-378.

hiwatashi, K. 1985. Fertilisation in Paramecium. In Metz, C. B. and Monroy, A. (eds) Biology of Fertilisation, Vol. 1, Academic Press, New York, pp. 57-85.

KITAMURA, A. 1982. Attachment of Paramecium to polystyrene surfaces: A model system for the analysis of sexual cell recognition and nuclear activation. J. Cell Sci., 58, 185-199.

KITAMURA, A. 1984. Evidence for an increase in the hydrophobicity of the cell surface during sexual interactions of Paramecium. Cell Structure and Function, 9, 91-95.

KITAMURA, A. 1985. Relation between mating type substance and adhesion molecules to polystyrene surfaces in ciliates. Jpn. J. Protozool, 18, 26-27.

KITAMURA, A. AND HIWATASHI, K. 1984. Inactivation of cell movement following sexual cell recognition in Paramecium caudatum. Biol. Bull., 166, 156-166.

LARISON, L. L. AND SIEGEL, R. W. 1961. Illegitimate mating in Paramecium bursaria and basis for cell union. J. Gen. Microbiol., 26, 499-508.
METZ, C. B. 1954. Mating substances and the physiology of fertilisation in ciliates. In Whenrich, D. H. (ed.) Sex in microorganisms, Am. Assoc. Adv. Sci., Washington, D.C., pp. 284-334.

MIYAKE, A. 1958. Induction of conjugation by chemical agents in Paramecium caudatum. J. Inst. Polytech. Oosaka City Univ., Ser. D., 9, 251-296.

MIYAKE, A. 1968. Induction of conjugation by chemical agents in Paramecium. J. Exp. Zool., 167, 359-380.

ORIAS, E., HAMILTON, E. P. AND FlACKS, M. 1979. Osmotic shock prevents nuclear transfer and produces wholegenome homozygotes in Tetrahymena. Science, 203, 660 663.

SIEGEL, R. W. 1963. New results on the genetics of mating types in Paramecium bursaria. Genet. Res., 4, 132-142.

SIEGEL, R. W. AND LARISON, L. L. 1960. The genic control of mating types in Paramecium bursaria. Proc. Natl. Acad. Sci., 46, 344-349.

SUHR-JESSEN, P. B. AND ORIAS, E. 1979. Mutants of Tetrahymena thermophila with temperature-sensitive food vacuole formation. I. Isolation and genetic characterisation. Genetics, 92, 1061-1077. 